\title{
KETERBUKAAN INFORMASI PUBLIK DALAM PENGELOLAAN DANA DESA DI KABUPATEN GOWA 2020
}

\author{
Aan Anugrah', Abdul Mahsyar ${ }^{2}$, Burhanuddin $^{3}$ \\ 1,2,3 Universitas Muhammadiyah Makassar \\ e-mail: ${ }^{1}$ aan@gmail.com, ${ }^{2}$ abdulmahsyar@gmail.com, ${ }^{3}$ burhanuddin2@gmail.com
}

\begin{abstract}
Abstrak
Penelitian ini bertujuan untuk menganalisis keterbukaan informasi publik dalam pengelolaan dana desa di Kabupaten Gowa. Penelitian ini merupakan penelitian dengan pendekatan kualitatif. Desa yang menjadi objek penelitian yakni, Desa Panaikang, Desa maccinibaji, desa bontobiraeng utara dan Desa Biringala. Sebanyak tujuh asas keterbukaan informasi publik digunakan sebagai instrument penelitian. Informan pada penelitian ini adalah pejabat kepala desa dan sekretaris desa. Teknik pengumpulan data dilakukan dengan wawancara, observasi dan dokumentasi. Teknik analisis data dilakukan dengan cara reduksi data, penyajian data dan penarikan kesimpulan. Uji keabsahan data dalam penelitian kualitatif meliputi uji, credibility, transferability, dependability, dan confirmability. Hasil penelitian menunjukkan bahwa dari keseluruhan 7 asas keterbukaan informasi publik hanya 6 yang sudah dijalankan dengan baik dan 1 asas masih diperlukan perbaikan dan peningkatan dalam menerapkannya, adapun faktor kendala yaitu kualitas SDM yang kurang Efektif sebagai faktor internal dan sarana dan prasarana informasi yang belum diterapkan dengan sistem online sebagai kendala eksternal.
\end{abstract}

Kata Kunci: Keterbukaan Informasi publik, Pengelolaan dana desa.

\begin{abstract}
This research was conducted to analyze the openness of public information in the management of village funds in Gowa Regency. This research is a research with a qualitative approach. The villages that were the object of the research were Panaikang Village, Maccinibaji Village, North Bontobiraeng Village and Biringala Village. A total of seven principles of public information disclosure were used as research instruments. The informants in this study were the officials of the village head and the village secretary. The data collection technique is done by interview, observation and documentation. The data analysis technique was done by reducing the data, presenting the data and drawing conclusions. The data validity test in qualitative research includes test, credibility, transferability, dependability, and confirmability. The results showed that of the total 7 principles of public information disclosure, only 6 had been implemented properly and 1 principle still needed improvement and improvement in implementing it, as for the constraining factors, namely the quality of human resources that was less effective as an internal factor and information facilities and infrastructure that had not been implemented properly. online system as an external constraint.
\end{abstract}

Keywords: Openness of public information, management of village funds.

\section{PENDAHULUAN}

Keterbukaan informasi alokasi dana desa kepada masyarakat belum bisa terlaksana dengan baik, dalam proses pembuatan sebuah keputusan dalam alokasi dana yang dibuat secara tertulis tersedia untuk warga yang membutuhkan, dengan setiap keputusan yang diambil sudah memenuhi standar etika dan nilai-nilai yang berlaku dan sesuai dengan prinsip-prinsip administrasi yang benar, hanya saja hal ini tidak dipublikasikan dengan baik kepada semua masyarakat. Dimensi transparansi ditemukan bahwa secara keseluruhan pada dimensi ini sudah berjalan dengan baik seperti kerjasama yang terjalin sudah dan semua masyarakat serta aparatur pemerintah sudah bekerja untuk saling mendukung, hanya saja terkadang permasalahan terjadi karena biasanya tidak semua kegiatan dapat diinformasikan kepada masyarakat sehingga 
terjadi pemberitaan yang membuat masyarakat berpandang negatif.

Secara umum Penerapan asas Keterbukaan informasi publik dalam pengelolan dana desa merupakan aspek penting dalam mencapai good governance dan merupakan salah satu proses evaluasi yang dilakukan mulai dari tahap perencanaan sampai dengan laporan pertanggungjawaban. Proses pelaksanaan evaluasi oleh Pemerintah pusat dilakukan secara sinergis serta terpadu. Hal itu sangat diperlukan untuk memastikan penggunaan Dana Desa sesuai dengan prioritas yang ditetapkan serta untuk memastikan bahwa ketercapaian output bisa lebih maksimal.

Isu tentang desa adalah salah satu isu pembangunan yang menarik banyak pihak dalam beberapa tahun terakhir Presiden Jokowi memposisikan desa sebagai target utama pembangunan yang tertuang dengan Nawacita yakni membangun Indonesia dari pinggiran dengan memperkuat daerah-daerah dan desa dalam kerangkanegara kesatuan sehingga desa menjadi salah satu bagian dari Kementerian desa,transmigrasi dan daerah tertinggal (Sulistyowati, 2017)

Pemerintah Kabupaten Gowa sejak tahun 2015 sudah mensosialisasikan penggunaan aplikasi Sistem Keuangan Dana Desa (Siskeudes), merupakan alat keterbukaan Informasi Publik dan merupakan langkah yang diambil oleh Pemerintah Kabupaten Gowa demi tercapainya Partisipatif, Transparan, Akuntabel, serta tertib dan disiplin anggaran yang bisa menjadi solusi dalam pengelolaan keuangan desa dan pembangunan desa yang baik. Namun berdasarkan laporan dari (Tribun-Timur.com, 2019) bahwa terdapat adanya dugaan penyalahgunaan dana desa di 32 Desa di Kabupaten Gowa, pengelolaan Dana Desa di 32 Desa ini masih ditemui beberapa permasalahan yang dimaksud meliputi Keterbukaan Informasi Publik dalam Pengelolaan Dana Desa, yaitu mulai sejak menyediakan dokumen anggaran menyediakan pengumuman kebijakan anggaran desa, dan mudah diakses oleh masyarakat, menyediakan laporan pertanggung jawaban yang tepat waktu, mengakomodir suara atau usulan masyarakat dan menye-diakan sistem pemberian informasi kepada masyarakat desa. Berdasarkan hal tersebut, peneliti menganggap perlu melakukan sebuah penelitian yang berkaitan dengan masalah tersebut, dengan menganalisis keterbukaan informasi publik dalam pengelolaan dana desa dengan mengukur Tersedianya informasi yang memadai, informasi pelayanan bebas diperoleh oleh siapapun, Informasi yang diberikan tepat waktu dalam rangka evaluasi dan monitoring, Tersedianya sarana dan prasarana informasi yang baik, adanya akses bagi masyarakat pada informasi yang siap tersedia, informasi mudah dijangkau, Sikap terbuka aparatur pemerintah dalam menyampaikan informasi Desa dalam pengelolaan keuangan desa.

\section{KAJIAN LITERATUR}

Tugas untuk mengelola informasi dalam jumlah besar adalah sebuah tantangan bagi banyak organisasi. Ketika pilihan untuk saluran-saluran komunikasi meningkat, jumlah pesan yang dikirim dan diterima serta kecepatan untuk mengirim pesan tersebut meningkat pula. Organisasi tidak hanya dihadapkan pada tugas untuk mengartikan pesan yang diterima, tetapi juga menghadapi tantangan untuk menentukan siapa yang harus menerima informasi yang disampaikan oleh organisasi tersebut.

Perhatian utama dari teori informasi organisasi adalah pengorganisasian informasi yang memiliki peranan penting bagi suksesnya sebuah organisasi. Sangat jarang bahwa satu divisi dalam suatu organisasi mempunyai semua informasi penting mengenai perusahaan tersebut. Informasi tersebut berasal dari berbagai macam sumber, yakni dari berbagai divisi yang ada di organisasi tersebut. Bagian tersulit dalam tugas pemrosesan informasi dalam suatu organisasi adalah mengartikan dan mentrasmisikan informasi yang didapatkan tersebut. (Morissan, 2009. hal:33)

Dalam Penjelasan Undang Undang Nomor 25 Tahun 2009 tentang Pelayanan Publik, khususnya Pasal 4 huruf h memberikan batasan tentang prinsip keterbukaan dalam pelayanan publik, antara lain dijelaskan bahwa setiap penerima pelayanan dapat dengan mudah mengakses dan memperoleh informasi mengenai pelayanan yang diinginkan. Menurut BAPPENAS prinsip keterbukaan sedikitnya memiliki 7 (tujuh) indikator, meliputi:

1) Tersedianya informasi yang memadai pada setiap proses penyusunan dan implementasi pelayanan publik; 
2) Informasi pelayanan bebas diperoleh oleh siapapun;

3) Informasi yang diberikan tepat waktu dalam rangka evaluasi dan monitoring;

4) Tersedianya sarana dan prasarana informasi yang baik;

5) Adanya akses bagi masyarakat pada informasi yang siap tersedia;

6) Informasi mudah dijangkau;

7) Sikap terbuka aparatur pemerintah dalam menyampaikan informasi.

Selanjutnya dalam Undang Undang dimaksud, khususnya Pasal 1 Angka (1) dikatakan bahwa: pelayanan publik adalah kegiatan atau rangkaian kegiatan dalam rangka pemenuhan kebutuhan pelayanan sesuai dengan peraturan perundang-undangan bagi setiap warga negara dan penduduk atas barang, jasa, dan/atau pelayanan administratif yang disediakan oleh penyelenggara pelayanan publik. Konsep keterbukaan dalam pelayanan menunjuk pada suatu keadaan dimana segala aspek dari proses penyelenggaraan pelayanan bersifat terbuka dan dapat di akses dengan mudah oleh para pengguna pelayanan dan stakeholders yang membutuhkan.

Jika segala aspek penyelenggaraan pelayanan, khususnya yang berkaitan dengan hak dan kewajiban antara pemberi/ penyelenggara layanan dengan pengguna layanan dapat diakses dengan mudah dan dipublikasikan secara terbuka sehingga mudah dipahami oleh publik, maka praktek penyelenggaraan tersebut memiliki tingkat keterbukaan yang tinggi, seperti: persyaratan, waktu, biaya, alur pelayanan, mekanisme pengaduan dan sebagainya. Sebaliknya manakala semua atau sebagian dari aspek pelayanan tidak terbuka dan sulit untuk di akses oleh para pengguna layanan maupun para stakeholders, maka penyelenggaraan pelayanan tersebut memiliki tingkat keterbukaan yang rendah, atau dengan kata lain tidak memenuhi kaidah keterbukaan (Suharno dalam Jumrah, 2013).

Agus Dwiyanto dalam Jumrah, (2013) mengatakan bahwa nilai budaya keterbukaan dapat memberikan dampak yang komplek dalam penyelenggaraan pemerintahan maupun pelayanan publik, antara lain :

1) Karena keterbukaan merupakan salah satu prinsip utama, sehingga akan mempunyai peranan yang signifikan untuk terwujudnya Good governance sebagai visi yang ingin dicapai dalam program Reformasi Birokrasi.

2) Keterbukaan juga dapat membawa dampak terhadap peningkatan partisipasi dalam pelayanan publik, karena masyarakat akan berpartisipasi aktif apabila diberikan akses dan informasi yang seluas-luasnya dan mudah mengenal pelaksanaan kegiatan pelayanan publik, serta hak dan kewa-jibannya sebagai pengguna layanan.

3) Keterbukaan juga memiliki keterkaitan yang erat dengan akuntabilitas publik, karena publik akan bersedia dan mampu untuk mengevaluasi kebijakan pelayanan publik, seandainya publik diberi kesempatan yang seluas-luasnya dan mudah untuk mengakses dan memperoleh informasi terhadap kebijakan dan tindakan yang dilakukan oleh Birokrasi sebagai penye-lenggara/ penyedia layanan

4) Keterbukaan juga akan menberikan kontribusi yang sangat besar dalam upaya penegakkan hukum dan pemberantasan KKN. Karena publik dapat menjadi apatis dalam menyikapi upaya penegakkan hukum dan pemberantasan KKN sebagai akibat aparat penegak hukum yang seringkali tidak transparan dalam proses penegakkan hukum dan praktek tebang pilih.

Dana Desa adalah dana yang bersumber dari APBN yang diperuntukkan bagi desa yang ditransfer melalui APBD kabupaten/kota dan digunakan untuk membiayai penyelenggaraan pemerintahan, pelaksanaan pembangunan, pembinaan kemasyarakatan, dan pemberdayaan masyara-kat. Penerapan asas Keterbukaan informasi publik dalam pengelolan dana desa merupakan aspek penting dalam mencapai good governance dan merupakan salah satu proses evaluasi yang dapat dilakukan.

1) Sri Mulyaningsih (2019) menunjukan bahwa Kepala Pekon Simpangkanan dalam pengelolaan Alokasi Dana Desa tidak transparan. Hal tersebut dikarenakan Kepala Pekon Simpangkanan tidak terbuka kepada masyarakat terkait dengan pengelolaan Alokasi Dana Desa.

2) Robiansyah Eka Pratama (2018) menunjukkan bahwa pengelolaan dana 
desa di desa-desa yang ada di Kecamatan Natar Kabupaten Lampung Selatan cukup baik untuk menerapkan prinsip dan aturan mengenai akuntabilitas. Namun, untuk prinsip transparansi, dan partisipasi dalam pengelolaan dana desa masih belum maksimal dilaksanakan baik.

3) Adianto Asdi Sangki, Ronny Gosal dan Josef Kairupan (2016) menunjukkan bahwa tidak adanya keterbukaan/ tranparansi mengenai anggaran yang dikelola pemerintah desa dalam hal ini pelaksanaa anggaran, sehingga masyarakat pada umumnya tidak mengetahui secara terperinci tentang APBDes.

4) Alfasadun, Pancawati Hardiningsih, Sri Devi Ratnasari dan Ceacilia Srimindarti (2018) menunjukkan bahwa pengelolaan keuangan desa belum sepenuhnya berjalan baik sesuai Permendagri Nomor 113 tahun 2014 dan Perbup Pekalongan tahun 2015.

5) Hanni Andini (2018) menunjukkan bahwa Pemerintah Desa Sinduharjo telah menerapkan prinsip akuntabilitas dan prinsip transparansi dalam pengelolaan keuangan desa.

\section{METODE}

Jenis penelitian yang digunakan adalah metode penelitian kualitatif, dilakukan dengan meneliti secara langsung ke lokasi penelitian untuk melihat secara langsung penerapan asasasas Keterbukaan informasi publik dalam penegelolaan dana desa, serta melakukan wawancara dengan beberapa Informan yang dianggap dapat memberikan informasi mengenai pelaksanaan Konsep Keterbukaan informasi publik dalam penegelolaan dana desa tersebut.

Tipe penelitian yang digunakan adalah tipe Studi kasus adalah penelitian yang memanfaatkan wawancara terbuka untuk menelah dan memahami sikap, pandangan, perasaan, dan perilaku individu atau sekelompok orang, yang terjadi dalam proses Keterbukaan informasi publik dalam pengelolaan dana desa.

Informan pada penelitian ini adalah pejabat kepala desa dan sekretaris desa. Teknik pengumpulan data dilakukan dengan cara wawancara, observasi dan dokumentasi.
Teknis analisis data kualitatif dilakukan secara interaktif dan berlangsung secara terus menerus sampai tuntas, sehingga datanya jenuh. Aktivitas dalam analisis data, yaitu : data reduction, data display dan conclusion.

Keabsahan data dilakukan untuk membuktikan apakah penelitian yang dilakukan benar-benar merupakan penelitian ilmiah sekaligus untuk menguji data yang diperoleh. Uji keabsahan data dalam penelitian kualitatif meliputi uji credibility, transferability, dependability, dan confirmability.

\section{HASIL DAN PEMBAHASAN}

\section{Ketersedian informasi yang memadai.}

Ketersediaan informasi pelayanan publik yang selalu terbaru dan transparan merupakan kebutuhan mutlak diperlukan. Pelayanan kepada masyarakat berupa informasi mengenai data dan dokumen yang diperlukan secara lengkap. Fungsi sesungguhnya informasi adalah untuk mengurangi ketidakpastian dalam sistem komunikasi disuatu lembaga atau organisasi. Pada bagian asas yang pertama diajukan 3 pertanyaan terkait ketersediaan informasi yang memadai, diantaranya terkait: (1) Ketersediaan Informasi pengelolaan dana desa, (2) Informasi Pengelolaan dana desa mudah diperoleh, (3) Bentuk Informasi pengelolaan dana desa.

Ketiga desa yang lainpun menjawab dengan maksud yang sama, seperti yang dikemukakan oleh Kepala Desa Biringala, Bapak MA yang mengatakan bahwa:

\section{Kebebasan Memperoleh Pelayanan}

Warga Negara mempunyai hak untuk mengetahui rencana pembuatan kebijakan publik, program kebijakan publik, dan program pengambilan keputusan publik, serta alasan pengambilan keputusan publik tersebut, begitupun juga dengan pengelolaan dana desa maka pemerintah desa perlu memberikan informasi pelayanan yang bebas kepada semua masyarakat desa.

Berdasarkan penelitian yang dilakukan pada empat Desa yang dipilih di kabupaten Gowa mengenai informasi pelayanan bebas diperoleh oleh siapapun yang terdiri dari tiga aspek yaitu (1) Pemberian akses masyarakat 
untuk mendapatkan pelayanan, (2) Kesiapan aparatur desa meningkatkan pelayanan (3) Publikasi informasi pelayanan.

Pada dasarnya keempat desa yang menjadi objek penelitian telah memenuhi asas keterbukaan informasi publik poin kedua, dibuktikan dengan ke empat pejabat desa telah menghimbau agar memberikan kebebasan tentang Informasi pengelolaan dana desa akan mendukung pelayanan kepada masyarakat.

\section{Ketepatan Pemberian Informasi}

Informasi yang berkualitas membutuhkan data yang tepat waktu. Tepat waktu merujuk pada ketersediaan data pada waktu yang diperlukan untuk dapat digunakan dalam kebutuhan tertentu. Informasi yang berkualitas berasal dari data yang dapat diolah dan dihasilkan secara cepat dan tepat agar pemanfaatannya tepat guna.

Berdasarkan penelitian yang dilakukan pada empat desa yang dipilih di kabupaten Gowa mengenai Informasi yang diberikan tepat waktu dalam rangka evaluasi dan monitoring yang terdiri dari tiga pertanyaan yakni (1) Penyampaian informasi tepat waktu (2) ketersediaan informasi (3) pelayanan informasi.

Kepala Desa Bontobiraeng Utara sudah menyampaikan informasi yang tepat waktu tentang pengelolaan dana Desa kepada masyarakat dibuktikan dengan realisasi pemerintah desa dalam memberikan informasi-informasi sesuai keinginan dan dibutuhkan masyarakat tepat pada waktunya.

Informasi yang diberikan tepat waktu akan mendukung pemberian pelayanan kepada masyarakat di Desa Maccinibaji dibuktikan dengan pahamnya masyarakat bagaimana untuk memperoleh pelayanan dan memperoleh informasi tentang pengelolaan dana Desa dikantor Desa.

Berdasarkan jawaban responden pada keempat Desa mengenai informasi yang diberikan tepat waktu. Maka didapatkan hasil penelitian bahwa di Kabupatan Gowa terkhusus pada empat sampel Desa yang diteliti, tentang informasi yang diberikan tepat waktu dalam pengelolaan dana Desa. menurut pengamatan peneliti selama ini, informasi pelayanan tentang informasi mengenai pengelolaan dana Desa kepada masyarakat di
4 Desa ini telah disampaikan dengan tepat waktu.

\section{Tersedianya sarana dan prasarana informasi yang baik.}

Undang Undang No 14 Tahun 2008 tentang Keterbukaan Informasi Publik mengamanatkan Badan Publik untuk mempublikasikan informasi yang dimiliki melalui media yang murah dan mudah dijangkau oleh masyarakat. Yang dimaksud Badan Publik adalah Lembaga yang sebagian kecil ataupun seluruh anggarannya dibiayai oleh APBN / APBD

Untuk itu Pemerintahan Desa yang sebagian besar anggarannya diperoleh dari APBN dan APBD, juga memanfaatkan website resmi desa.id sebagai salah satu wujud Keterbukaan informasi publik. Dalam hal sarana dan prasaranan informasi publik untuk mengoptimalan pelayanan informasi sangat diperlukan guna terlaksananya tugas dan fungsi sesuai kewenangan masing-masing perangkat Desa kepada masyarakat.

Kepemilikan situs website bagi suatu organisasi pemerintah yang memberikan layanan publik merupakan satu langkah dalam mewujudkan e-service pada pelayanan yang berkualitas. Fungsi website adalah sebagai media sosialisasi informasi proses dan syaratsyarat pelayanan oleh masyarakat. Sedangkan hasil dari temuan penelitian di lapangan, Sarana Informasi yang digunakan diDesa Panaikang belum melalui sarana Informasi lewat website yang akan memberikan kemudahan bagi masyarakat yang ingin mendapatkan informasi tentang pengelolaan dana Desa. Sarana informasi yang dimiliki kantor Desa hanya berupa papan pengumuman yang terpa-sang dihalaman kantor Desa.

Sosialisasi secara online yang digunakan merupakan implementasi dari kebijakan yang berbasis website terkait dengan pelayanan publik, pemberian informasi melalui website merupakan upaya untuk memanfaatkan teknologi informasi dan komunikasi dimaksudkan untuk meningkatkan efesiensi, efektifitas, transparansi dan akuntabilitas penyelenggaraan pelayanan. Terkait dengan hasil wawancara mengenai penggunaan website sebagai sarana informasi kepada masyarakat peneliti mendapatkankan hasil bahwa diDesa Biringala belum melalui sarana 
Informasi lewat website yang akan memberikan kemudahan bagi masyarakat yang ingin mendapatkan informasi tentang pengelolaan dana Desa. Sarana informasi yang dimiliki kantor Desa hanya berupa papan pengumuman yang terpasang dihalaman kantor Desa dan dibantu oleh aplikasi facebook untuk media online nya

Berdasarkan penelitian yang dilakukan pada empat Desa yang dipilih di kabupaten Gowa mengenai tersedianya sarana dan prasarana informasi yang baik dirangkum berdasarkan jawaban responden pada keempat Desa mengenai sarana dan prasarana informasi. Maka didapatkan hasil penelitian bahwa di Kabupatan Gowa terkhusus pada empat sampel Desa. Menurut peneliti di 4 Desa masih menggunakan sarana dan prasarana yang masih manual baik itu bulletin dan majalah yang dapat dijadikan media informasi pelayanan kepada seluruh masyarakat tentang pengelolaan dana desa belum tersedia disana. Di kabupaten gowa sendiri masih banyak desa yang belum memanfaatkan media informasi online dan cetak dengan baik dan penyediaan informasi masih sangat terbatas dengan sarana dan prasarana seadanya.

\section{Adanya akses bagi masyarakat pada informasi yang siap tersedia.}

Pembangunan sistem informasi perdesaan juga dapat memutus kesenjangan politik, ekonomi, sosial dan budaya. Sistem informasi perdesaan yang baik kemudian akan mendorong keterbukaan informasi publik hingga ke level perdesaan. Keterbukaan dan transparansi pasca terbitnya UU Desa menjadi sangat penting untuk mencegah penyimpangan penggunaan dana desa oleh perangkatnya.

Selain itu, adanya pusat-pusat informasi dipedesaan akan meningkatkan partisipasi masyarakat dalam pembangunan. Tentunya sistem informasi perdesaan harus dirancang dengan model komunikasi dua arah, baik antara masyarakat desa dengan perangkatnya, maupun dengan pemerintah daerah. Partisipasi dalam kegiatan pengelolaan dana Desa penting dilakukan untuk mening-katkan keterlibatan masyarakat sejak peren-canaan, pelaksanaan hingga pengawasan pembangunan Desa.

Masyarakat mempunyai hak untuk mengetahui Informasi yang ada di pemerintah
Oleh karena itu tentunya seluruh masyarakat memiliki akses terhadap informasi yang telah tersedia, Badan publik sebagai salah satu intansi pemerintahan di Desa yang mempunyai tugas utama memberikan akses untuk pelayanan kepada masyarakat. Pemerintah Desa Panaikang Sudah memberikan akses tentang informasi pengelolaan dana Desa kepada masyarakat dibuktikan dengan adanya akses yang disediakan pemerintah Desa bagi masyarakat yang membutuhkan informasi dikantor Desa.

Pemerintah Desa Biringala Sudah memberikan akses tentang informasi pengelolaan dana Desa kepada masyarakat dibuktikan dengan adanya akses yang disediakan pemerintah desa dikantor desa dan memberikan informasi yang dibutuhkan masyarakat.

Pemerintah Desa Bontobiraeng Utara Sudah memberikan akses tentang informasi pengelolaan dana Desa kepada masyarakat dibuktikan dengan adanya akses yang disediakan pemerintah desa bagi masyarakat yang membutuhkan informasi dikantor desa.

Pemerintah Desa Maccinibaji Sudah memberikan akses tentang informasi pengelolaan dana Desa kepada masyarakat dibuktikan dengan adanya akses yang disediakan pemerintah Desa bagi masyarakat yang membutuhkan informasi dikantor Desa.

Berdasarkan jawaban responden pada keempat Desa mengenai Adanya akses bagi masyarakat pada informasi yang siap tersedia. Maka didapatkan hasil penelitian bahwa di Kabupatan Gowa terkhusus pada empat sampel Desa yang diteliti, tentang Adanya akses bagi masyarakat pada informasi yang siap tersedia dalam pengelolaan dana Desa, Kalau menurut pengamatan saya selama ini, akses untuk memperoleh informasi sangat terbuka. Kalau butuh informasi, masyarakat bisa langsung datang ke kantor Desa untuk menjumpai petugas yang ada dan informasi yang dibutuhkan akan didapatkan.

\section{Informasi mudah dijangkau}

Informasi yang baik terlihat dari kemudahan informasi tersebut untuk diakses dan dijangkau oleh masyarakat. Masyarakat juga memiliki hak untuk informasi tentang pengelolaan dana Desa. Oleh karena itu tentunya seluruh masyarakat harus diberi 
kemudahan untuk mendapatkan informasi yang telah dibutuhkan.

Kemudahan dalam mengakses data, Pelayanan yang baik juga dapat diwujudkan perangkat desa dengan memberikan kemudahan dalam mengakses data kepada masyarakat. Perangkat Desa memberikan pelayanan untuk membantu masyarakat kapan saja dibutuhkan dalam mengakses data, Memberikan pelayanan yang baik kepada masyarakat merupakan bentuk untuk mengembangkan prinsip transparansi pada pemerintahan desa kabupaten Gowa.

Pedoman untuk mendapatkan informasi juga sangat penting didalam memberikan informasi kepada masyarakat maka perlu dimaksimalkan oleh pemerintah dalam membuat aturan tentang tahapan-tahapan yang mudah dipahami oleh masyarakat untuk mendapatkan informasi yang dibutuhkannya. Pemerintah Desa Dikantor Desa Panaikang sudah memberikan kemudahan kepada masyarakat untuk menjangkau informasi tentang pengelolaan dana Desa dibuktikan dengan tersedianya papan informasi tentang pengelolaan dana Desa yang bisa dijangkau oleh masyarakat.

Pemerintah Desa Dikantor Desa Biringala sudah memberikan kemudahan kepada masyarakat untuk menjangkau informasi tentang pengelolaan dana Desa dibuktikan dengan tersedianya baliho transparansi tentang pengelolaan dana desa yang bisa dijangkau oleh masyarakat.

Pemerintah Desa Dikantor Desa Bontobiraeng Utara sudah memberikan kemudahan kepada masyarakat untuk menjangkau informasi tentang pengelolaan dana Desa dibuktikan dengan tersedianya baliho spanduk tentang pengelolaan dana Desa yang dipajang didepan kantor Desa yang bisa dijangkau oleh masyarakat.

Pemerintah Desa Dikantor Desa Maccinibaji sudah memberikan kemudahan kepada masyarakat untuk menjangkau informasi tentang pengelolaan dana Desa dibuktikan dengan tersedianya papan spanduk yang tentang pengelolaan dana Desa dipajang didepan kantor Desa yang bisa dijangkau oleh masyarakat.

Berdasarkan jawaban Informan pada keempat Desa mengenai informasi yang diberikan tepat waktu. Maka peneliti mendapatkan hasil bahwa di Kabupatan Gowa terkhusus pada empat sampel Desa yang diteliti, Pemerintah Desa selalu mengupayakan agar masyarakat mudah menjangkau informasi pengelolaan dana Desa kepada masyarakat dan sosialisasi juga telah berjalan dengan lancar melalui musyawarah dan Masyarakat juga difasilitasi informasi pelayanan tentang pengelolaan dana Desa tersebut melalui baliho yang dipajang didepan kantor Desa.

\section{Sikap terbuka aparatur pemerintah dalam menyampaikan informasi}

Sebagai pelayan, tentu saja aparatur pemerintah harus memahami keinginan dan harapan masyarakat yang harus dilayaninya. Meningkatnya pengetahuan dan kesadaran masyarakat akan hak-haknya sebagai dampak globalisasi yang ditandai revolusi dibidang telekomunikasi, teknologi informasi, transportasi telah mendorong munculnya tuntutan gencar yang dilakukan masyarakat kepada pejabat publik untuk segera merealisasikan penyelenggaraan tata kelola pemerintahan yang baik (good governance).

Sebagai pelaksana pemerintahan di desa aparatur pemerintah perlu terbuka untuk menjalankan tugas dan peran masing-masing perangkat desa dalam menyampaikan informasi kepada masyarakat.

Instansi pemerintah sebagai badan publik wajib mnyediakan informasi dibawah kewenangannya yang mengandung kebenaran dan mudah untuk dijangkau masyarakat. kewajiban menyampaikan dan memberikan informasi kepada masyarakat dengan terbuka dan tidak di tutup-tutupi. Sikap pemerintah Desa di Desa Panaikang dalam memberikan informasi pelayanan kepada masyarakat sudah terbuka dibuktikan dengan sikap aparatur pemerintah Desa yang terbuka pada saat masyarakat menanyakan informasi tentang suatu pelayanan dan informasi lainnya aparatur Desa langsung memberitahukannya kepada masyarakat yang bertanya tersebut.

Sikap pemerintah Desa diDesa Biringala dalam memberikan informasi pelayanan kepada masyarakat sudah terbuka dibuktikan dengan sikap aparatur pemerintah Desa yang terbuka pada saat masyarakat menanyakan informasi tentang suatu pelayanan dan informasi lainnya aparatur desa langsung memberitahukannya kepada masyarakat yang memerlukan informasi. 
Sikap pemerintah desa di Desa Bontobiraeng Utara dalam memberikan informasi pelayanan kepada masyarakat sudah terbuka dibuktikan dengan sikap aparatur pemerintah Desa yang terbuka pada saat masyarakat menanyakan informasi tentang suatu pelayanan dan informasi lainnya aparatur desa langsung memberitahukannya kepada masyarakat yang memerlukan informasi.

Sikap pemerintah desa di Desa Maccinibaji dalam memberikan informasi pelayanan kepada masyarakat sudah terbuka dibuktikan dengan sikap aparatur pemerintah desa yang terbuka pada saat masyarakat menanyakan informasi tentang suatu pelayanan dan informasi lainnya aparatur Desa langsung memberitahukannya.

Berdasarkan jawaban informan pada keempat Desa mengenai sikap aparatur pemerintah yang terbuka dalam menyampaikan informasi Maka didapatkan hasil penelitian bahwa pada empat sampel Desa yang diteliti. Menurut peneliti cukup baik tapi masih perlu dilakukan perbaikanperbaikan terutama dalam hal fasilitas yang digunakan dalam penyampaian informasi kepada masyarakat. Hendaknya pemerintah Desa memiliki inisiatif untuk menyampaikan informasi publik tentang informasi pengelolaan dana desa kepada masyarakat dengan memberikan fasilitas lain yang lebih baik, modern dan mudah dijangkau oleh masyarakat.

\section{Faktor Kendala Informasi Publik dalam pengelolaan dana Desa}

Pengelolaan dan pelaksanaan program atau kegiatan keuangan Desa sudah barang tentu ditemukan masalah. Hal tersebut menunjukkan bahwa pengelolaan dana Desa sebagai bagian dari keuangan desa juga memiliki masalah dan faktor yang menjadi penghambat baik itu kendala Internal maupun kendala eksternal.

Pada penjelasan kendala penggunaan dana Desa tidak dijelaskan di tiap desa, dikarenakan kendala bisa saja timbul di setiap Desa seiring berjalannya waktu. Sehingga kendala yang disampaikan di tiap Desa akan dianggap sebagai kendala bersama dalam penggunaan Dana Desa. Karena bukan tidak mungkin kendala yang ada di suatu desa akan terasa di desa lainnya pada waktu yang akan datang.

Berdasarkan penelitian yang dilakukan pada empat desa yang dipilih di kabupaten Gowa mengenai Faktor kendala keterbukaan informasi publik dalam pengelolaan dana Desa yakni:

1) Kendala Internal

Kendala Internal adalah Pelakasanaan pelayanan dalam memberikan informasi kepada masyarakat, ada beberapa hal yang mesti diperhatikan yakni, regulasi dalam bidang pelayanan kepada masyarakat, system informasi yang mesti jelas Khususnya pada pelayanan rutin dan kegiatan SDM dalam menangani pelayanan publik

Kendala pemerintah Desa dalam relgulasi biasa disebabkan oleh SDM yang kurang memadai dalam memilah aturan-aturan yang baik diberlakukan untuk memberikan pelayanan kepada masyarakat tentang informasi-informasi yang dibutuhkan masyarakat. Terkait dengan upaya regulasi pemerintah Desa dikantor Desa Panaikang tentang pengelolaan dana Desa terkendala dengan kurangnya kualitas SDM yang memadai dibuktikan dengan perangkat Desa yang hanya bisa menyusun perencanaan yang mereka ketahui saja karna keterbatasan pendidikan pada perangkat Desa.

Terkait dengan upaya regulasi pemerintah desa dikantor Desa Biringala tentang pengelolaan dana desa terkendala dengan kurangnya kualitas SDM yang memadai dibuktikan dengan perangkat Desa yang tidak semuanya paham dengan pekerjaannya dikantor Desa dan Biasanya pekerjaan bertumpu pada satu atau dua orang saja yang paham dengan pekerjaan yang ada dikantor desa.

Terkait dengan upaya regulasi pemerintah desa dikantor Desa Bontobiraeng Utara tentang pengelolaan dana Desa tidak memiliki kendala apapun dibuktikan dengan semua perangkat Desa paham dengan pekerjaannya masing-masing dan bisa menyelesaikan pekerjaannya dikantor desa.

Berdasarkan penelitian yang dilakukan pada empat desa yang dipilih di kabupaten Gowa mengenai Faktor kendala Internal keterbukaan informasi publik dalam pengelolaan dana Desa yang disampaikan oleh 4 Desa Yaitu Kepala Desa Biringala, Kepala 
Desa Bontobiraeng utara, Kepala Desa Panaikang dan Sekretaris Desa Maccinibaji Maka didapatkan hasil penelitian bahwa pada empat sampel desa yang diteliti. Menurut peneliti kendala internal di ke empat Desa terkendala pada SDM dikantor Desa yang kurang memadai. Hendaknya pemerintah Desa memiliki inisiatif untuk mengupayakan peningkatan SDM dengan memberikan bimbingan teknis dan mengikut sertakan aparatur Desa untuk mengikuti pelatihanpelatihan mengenai manajemen pekerjaan.

\section{2) Kendala Eksternal}

Kendala Eksternal adalah pelaksanaan pelayanan dalam memberikan informasi kepada masyarakat, ada beberapa yang mesti diperhatikan yakni, sarana dan prasarana dalam memberikan informasi kepada masyarakat

Kendala Eksternal adalah pelaksanaan pelayanan dalam memberikan informasi kepada masyarakat, ada beberapa yang mesti diperhatikan yakni, pemberikan informasi melalui media cetak kepada masyarakat. Sebagai pemerintah desa diharapkan untuk mengupayakan didalam memberikan informasi melalui media cetak kepada masyarakat tentang pengelolaan dana desa.

Dengan adanya media cetak majalah atau bulletin, informasi dari pemerintah dapat di sebarluaskan kepada masyarakat dengan mudah, sehingga manfaat yang dihasilkan informasi dapat diakses oleh masyarakat walaupun hanya dirumah, proses penyebaran informasi melalui sistem ini merupakan satu cara yang dapat dilakukan untuk meningkatkan kualitas pelayanan publik untuk mempermudah penyampaian informasi kepada masyarakat yang dibagikan kepada masyarakat untuk mengetahui informasi tentang pengelolaan dana Desa. Kendala Pemerintah Desa Panaikang terkait dengan Penyampaian Informasi penggunaan dana Desa tidak tersampaikan melalui media cetak terbukti dengan penyampaian Informasi penggunaan dana Desa yang hanya tersampaiakan melalui baliho transparansi yang dipajang didepan kantor Desa.

Kendala Pemerintah Desa Biringala terkait dengan Penyampaian Informasi penggunaan dana desa tidak tersampaikan melalui media cetak terbukti dengan penyampaian Informasi penggunaan dana desa yang hanya tersampaiakan melalui baliho transparansi yang dipajang didepan kantor desa.

Kendala Pemerintah Desa Bontobiraeng Utara terkait dengan Penyampaian Informasi penggunaan dana Desa tidak tersampaikan melalui media cetak terbukti dengan penyampaian Informasi penggunaan dana Desa yang hanya tersampaiakan melalui baliho transparansi yang dipajang didepan kantor Desa.

Kendala Pemerintah Desa Maccinibaji terkait dengan Penyampaian Informasi penggunaan dana Desa tidak tersampaikan melalui media cetak terbukti dengan penyampaian Informasi penggunaan dana Desa yang hanya tersampaiakan melalui baliho transparansi yang dipajang didepan kantor Desa.

\section{KESIMPULAN}

Berdasarkan hasil penelitian dan analisis pembahasan di atas, maka kesimpulan dalam penelitian Tesis ini adalah sebagai berikut :

a. Penerapan asas keterbukaan informasi dalam pengelolaan dana Desa di Kabupaten Gowa di empat Desa yang menjadi objek penelitian yakni, Desa Panaikang, Desa maccinibaji, desa bontobiraeng utara dan Desa Biringala sudah menerapkan dengan baik 6 (enam) asas-asas keterbukaan informasi publik, sementara itu 1 (satu) asas keterbukaan informasi publik yaitu tersedianya sarana dan prasarana informasi yang baik masih perlu perbaikan dan peningkatan.

b. Faktor kendala internal keterbukaan informasi publik dalam pengelolaan dana desa di Kabupaten Gowa di empat Desa yang menjadi objek penelitian yakni, Desa Panaikang, Desa maccinibaji, desa bontobiraeng utara dan Desa Biringala adalah kualitas SDM yang kurang efektif sedangkan, Faktor kendala eksternal keterbukaan informasi publik dalam pengelolaan dana Desa di Kabupaten Gowa adalah sarana dan prasarana informasi yang belum diterapkan dengan sistem online, yang dimana informasi penggunaan dana Desa hanya dipajang pada baliho transparansi APBDesa. 


\section{REFERENSI}

Alfasadun, dkk (2018) "Transparansi dan Akuntabilitas Pengelolaan Dana Desa”. Jurnal. ISBN: 978-979-364999-3

Aminuddin ilmar, 2016. Hukum tata pemerintahan, prenadamedia group, Jakarta.

Aries Iswahyudi, Iwan Triyuwono \& M Achsin. Hubungan pemahaman akuntabilitas, transparansi, partisipasi, Value for money dan good gavernance. Desember 2016

Hanni Andini.(2018). "Penerapan Prinsip Akuntabilitas dan Prinsip Transparansi Dalam Pengelolaan Keuangan Desa”. Skripsi. Fakultas Ekonomi Universitas Sanata Dharma Yogyakarta.

Husin Thamrin, 2013 hukum pelayanan public di Indonesia, aswaja pressindo, Yogyakarta.

Infodesa (2020, 2 Juli) " 4 Asas utama pengelolaan keuangan desa". Diakses pada 2 Juli 2020, Pada https://risehtunong.blogspot.com/2015 /12/4-asas-utama-pengelola-keuangandesa.html?m=1

Jumrah, Siti.2013.”Analisis keterbukaan informasi dalam mendukung pelayanan public dikantor camat Kecamatan Kaway XVI Kabupaten Aceh Barat". Skripsi. Fakultas Ilmu Social dan Ilmu Politik. Universitas Teuku UmarMeulaboh : Aceh Barat

Juriaro ridwan \& ahmad sodik sudrajat, 2009, hukum administrasi Negara dan kebijakan pelayanan publik, nuansa, bandung

Kridawati sadhan.2010, etika birokrasi dalam pelayanan public, CV. Citra Malang, Malang.

Kridawati sadhan.2010, Etika birokrasi D Don F. (2000).komunikasi Organisasi: Strategi meningkatkan kinerja perusahaan. Bandung: PT. Remaja rosdakarya

Morissan. 2009. Manajemen media penyiaran; strategi mengelola radio dan televise. Jakarta: prenada media group.

Mohammad Ibrahim (2011, 7 Februari) "keterbukaan Informasi Publik (KIP) Secara Singkat". Diakses pada 2 Juli 2020 , pada http://belajarhukumindonesia.blogspot .co.id/2011/02/keterbukaan-informasipublik-kip-secara.html

Permendagri Nomor 113 Tahun 2014 tentang pengelolaan keuangan desa Robiansyah Eka Pratama (2018) "Akuntabilitas, Transparansi, Dan Partisipasi Dalam Pengelolaan Dana Desa (Studi Kasus Pada Desa di Kecamatan Natar Kabupaten Lampung Selatan)". Skripsi. Fakultas Ekonomi Dan Bisnis . Universitas Lampung:Bandar Lampung

Rusman Nurjaman, Fighting corruption from below:"strategi penguatan akuntabilitas local dalam pengelolaan keuangan desa" national institute of public administration republic of Indonesia: proceeding international seminar reconstructing public administration reform to build world class govermment, Agustus, 2017.

Sangki.A.A, Gosal.R. Kairupan.J.(2016) "Penerapan Prinsip Transparansi Dan Akuntabilitas Dalam Pengelolaan Anggaran Pendapatan Dan Belanja Desa (Suatu Studi Di Desa Tandu Kecamatan Lolak Kabupaten Bolaang Mongondow)" Jurnal. FISIP-Unsrat. Manado

Samsul, Arifin.2016. "Kajian penyelenggaraan kebijakan informasi publik (Studi kasus program diseminasi informasi diDishubkominfo Kabupaten Bangkalan tahun 2012-2015". Tesis. Fakultas Ilmu Social dan Ilmu Politik. Universitas Airlangga: Surabaya.

Setyoko, P.I (2011). Akuntabilitas Administrasi keuangan program alokasi dana desa (ADD). Jurnal Ilmu Administrasi Negara, 11(1)

Sri Mulyaningsih (2019). "Transparansi Pengelolaan Alokasi Dana Desa Pekon Simpangkanan". Skripsi. Fakultas Ilmu Sosial Dan Ilmu Politik. Universitas Lampung:Bandar Lampung

Suryani, Tanti Budi \& Ahmd Faisol. 2010. Klientelisme dan Praktik akses informasi di NTT. Dalam majalah prisma edisi:Masyarakat terbuka Indonesia Vol.30.jakarta:LP3ES.

Tim UJDIH Perwakilan Provinsi Sulawesi Tenggara, 2015 
JPPM: Journal of Public Policy and Management

p-ISSN : 2723-6633 | e-ISSN: 2715-2952

Volume 3 Nomor 1 | May, 2021 | page: 53-63

Undang-undang Nomor 14 Tahun 2008 tentang keterbukan informasi public

Undang- undang Nomor 6 tahun 2014 tentang desa

Undang-undang nomor 23 tahun 2014 tentang pemerintahan daerah

Yusran Lapananda, 2016, Hukum pengelolaan keuangan desa, PT. wahana semesta intermedia Jakarta. 